\title{
PENGARUH FEMALE EXECUTIVE TERHADAP KUALITAS LAPORAN KEUANGAN PADA SEKTOR MANUFAKTURYANG TERDAFTAR DI BEI PERIODE 2012-2014
}

\author{
Arief Kusumo Atmojo Sugiharto \\ Universitas Surabaya \\ Bonaventura16@hotmail.com \\ Felizia Arni Rudiawarni, S.E., M.Ak. \\ Universitas Surabaya \\ felizia@staff.ubaya.ac.id
}

\begin{abstract}
The purpose of this study was to examine the effect of female executives on the quality of financial statements of companies in the manufacturing sector. The quality of the company's financial statements can be seen from the tendency of directors of companies to do the earnings management. The object of this research is manufacturing companies listed in Indonesia Stock Exchange 2012-2014.

This study uses a quantitative approach and tested with the regression model. Independent variables used are Female, Leverage, Loss, M / B Ratio, Revenue Growth, Size, SIC and Year. The dependent variable used is Dicretionary Accruals as a proxy of earnings management. The results of this study indicate that the presence of women as an executive in the company turned out to give a good impact for the company, women tend to be more conservative in choosing strategy, particularly related to the financial statements.
\end{abstract}

Keywords : Female Executives, Earnings Management.

\section{PENDAHULUAN}

Saat ini kaum wanita tidak bisa lagi dipandang sebelah mata. Sejak era emansipasi, perbedaan gender sudah bukan menjadi masalah untuk menentukan kualitas seseorang. Dalam beberapa periode terakhir ini, wanita memang sangat menunjukkan eksistensinya sebagai seorang professional di bidangnya yang bisa mengalahkan kaum pria. Wanita memiliki keahlian dan kemampuan untuk menduduki posisi tertentu di sebuah perusahaan. Seperti kabar yang dirilis forbes, ada 3 pengusaha wanita sukses dari indonesia yang masuk dalam daftar Asia Power Woman, seperti Anne Patricia Sutanto (Vice President Director PT Pan Brothers Tbk.), Noni Purnomo (President Director Blue Bird), dan Wendy Sui 
Cheng Yap (President Director dan CEO PT Nippon Indosari Tbk.).(forbes dalam www.maxmanroe.com)

Dalam penelitian ini, peneliti ingin meneliti hubungan antara manajemen laba dan gender dari eksekutif suatu badan usaha. Lebih tepatnya penelitian ini berfokus pada gender Chief Executive Officer (CEO) dan Chief Financial Officer (CFO), bagaimana pengaruh perempuan sebagai eksekutif sebuah perusahaan dapat mempengaruhi kualitas dari laporan keuangan perusahaan.

Peneliti melakukan riset pendahuluan terhadap laporan tahunan untuk badan usaha yang terdaftar pada BEI periode 2014 (tanpa memasukan badan usaha sektor keuangan). Riset pendahuluan yang dilakukan peneliti berguna untuk memetakan proporsi eksekutif perempuan (CEO dan/ atau CFO) pada badan usaha yang terdaftar pada BEI. Hasil riset pendahuluan dapat dilihat pada tabel 1.

Tabel 1. Badan Usaha yang Memiliki CEO dan/atau CFO Perempuan pada Tahun 2014(selain Badan Usaha Sektor Keuangan)

\begin{tabular}{cccc}
\hline \multirow{2}{*}{ SEKTOR } & BADAN USAHA & BADAN USAHA YANG & PRESENTASE \\
& TERDAFTAR & MEMILIKI CEO DAN/ & (\%TAU CFO WANITA
\end{tabular}

$\begin{array}{cccc}\text { Primer } & 62 & 4 & 6.45 \% \\ \text { Sekunder } & 144 & 32 & 22.22 \% \\ \text { Tersier } & 218 & 37 & 16.97 \%\end{array}$

\section{Sumber: factbook 2015, data olahan}

Dari tabel 1. tampak bahwa sektor industri sekunder memiliki persentase CEO dan/atau CFO yang ada pada badan usaha yang terdaftar pada BEI tahun 2014. Sehingga penelitian ini berfokus pada sektor industri sekunder yang akan dijadikan sebagai objek penelitian untuk mengetahui hubungan eksekutif wanita terhadap earning management di badan usaha yang terdaftar pada BEI. 


\section{PENGEMBANGAN HIPOTESIS}

\subsection{Earnings management dan gender eksekutif}

Fernandes dan Cabral-Cardoso (2003) dalam Taleb (2010) menjelaskan bahwa peran gender bukan terbatas pada jenis kelamin atau keadaan biologis seseorang namun sebenarnya telah terbagi menjadi dua yaitu sifat sosial maskulinitas dimana melibatkan agresivitas, konfrontasi, kemandirian dan pengambilan keputusan serta sifat sosial feminitas dimana melibatkan emosi, kepekaan, dan intuisi.

Secara lebih jelas, Taylor (1997) menjelaskan bahwa perempuan cenderung akan menggunakan soft skill untuk kemampuan manajerialnya dan mengarah pada gaya feminitas. Hal inilah yang menjadi bukti mengapa kepemimpinan perempuan yang feminin seringkali disebut sebagai gaya kepemimpinan transformasional (Eagly et al, 1994) dalam Altintas dan Altintas (2008). Menurut Yukl (2010: 275), gaya kepemimpinan transformasional dimulai dengan bagaimana seorang pemimpin membangun nilai budaya organisasi dan akan berdampak positif terhadap motivasi pengikut maupun kinerja dibandingkan dengan gaya kepemimpinan transaksional.

Mengingat bahwa setiap kinerja badan usaha akan dievaluasi secara berkala, maka tidak salah jika kinerja badan usaha juga dikaitkan atau dihubungkan terhadap kualitas pelaporan laba. Kualitas pelaporan laba ini juga dapat dipengaruhi oleh perbedaan eksekutif (laki-laki atau perempuan) karena mereka sebagai eksekutif masih memiliki hak untuk mempengaruhi praktik pelaporan keuangan badan usaha (Peni dan Vahamaa, 2010). Salah satu contoh pilihan pelaporan keuangan yang dapat dilakukan oleh badan usaha adalah dengan melakukan tindakan oportunis berupa manajemen laba untuk mencapai tujuan tertentu (Scott, 2009), dimana manajemen laba ini sendiri akan berpengaruh pada kualitas pelaporan keuangan. Semakin tinggi kualitas pelaporan laba, biasanya akan semakin tinggi juga penilaian investor terhadap manajer. Tidak jarang bahwa ketika manajer ingin memenuhi ekspektasi investornya, ia dapat memilih untuk melakukan manajemen laba. Oleh karena itu, eksekutif yang berbeda juga akan berdampak pada kecenderungan praktik manajemen laba. 
Jianakoplos dan Bernasek (1998) dalam Darmadi (2013) menjelaskan bahwa perempuan akan cenderung untuk lebih menghindari risiko dibanding lakilaki dalam hal pengambilan keputusan keuangan. Selain itu, Loo (2003) menyatakan bahwa perempuan dapat dikatakan lebih etis dibandingkan laki-laki. Perempuan juga disebutkan oleh Heminway (2007) dalam Peni dan Vahamaa (2010) cenderung lebih dapat dipercaya dibandingkan dengan laki-laki. Hal yang juga penting adalah bahwa perempuan memiliki sikap konservatif yang lebih tinggi dibandingkan dengan laki-laki (Peni dan Vahamaa, 2010). Kelebihan sifat dan sikap yang dimiliki perempuan memberi bukti bahwa untuk mempertahankan posisi mereka sebagai eksekutif maka ia akan cenderung melakukan manajemen laba. Manajemen laba yang akan diterapkan oleh eksekutif perempuan di badan usaha biasanya berwujud strategi konservatif sehingga memberikan manfaat yang maksimal baik periode bersangkutan maupun periode-periode berikutnya. Oleh karena itu dapat disimpulkan bahwa terlepas dari motivasi dan pola manajemen laba, eksekutif perempuan sebagai pimpinan badan usaha berhubungan dengan kecenderungan praktik manajemen laba.

\subsection{Female Executive, firm performance, and earnings management}

Carter et al. (2003), Erhardt et al. (2003), Farrel dan Hersch (2005), Rose (2007), Campbell dan Minguez-Vera (2008), dan Adams dan Ferreira (2009) meneliti efek dari eksekutif dan direksi perempuan pada kinerja keuangan dan nilai pasar perusahaan. Erhardt et al. (2003) menggunakan sampel perusahaanperusahaan besar yang ada di Amerika untuk menguji hubungan antara board diversity dan kinerja keuangan. Mereka berpendapat bahwa keanekaragaman gender dapat menyebabkan basis pengetahuan yang lebih luas, yang dapat menciptakan keunggulan kompetitif. Dalam kasus yang sama Carter et al. (2003), Farrel dan Hersch (2005), dan Campbell dan Minguez-Vera (2008) berpendapat bahwa keanekaragaman gender berhubungan dengan peningkatan kinerja keuangan dan meningkatkan nilai perusahaan. Peni dan Vahamaa (2010) berpendapat bahwa jenis kelamin eksekutif perusahaan berpotensi memiliki implikasi untuk melakukan manajemen laba, selain itu jenis kelamin eksekutif juga dapat mempengaruhi kualitas laporan keuangan perusahaan. 
Beberapa penelitian memiliki pendapat yang berbeda bahwa keanekaragaman gender tidak mempengaruhi peningkatan kinerja perusahaan. Watson (2002) menunjukkan tidak ada perbedaan yang signifikan antara perusahaan yang dikendalikan oleh pria maupun wanita.Namun demikian, ia juga menemukan beberapa bukti yang menunjukkan bahwa perusahaan yang dikendalikan oleh perempuan dapat mengungguli perusahaan yang dikendalikan oleh laki-laki. Menggunakan data dari Denmark, Rose (2007) mengatakan tidak ada hubungan yang signifikan antara kinerja perusahaan dengan pemimpin wanita. Adams dan Ferreira (2009) berpendapat bahwa rata-rata efek direktur perempuan pada kinerja perusahaan adalah negatif.Mereka juga menemukan bahwa keragaman jenis kelamin dapat meningkatkan kinerja keuangan pada perusahaan dengan tata kelola perusahaan yang lemah.

Wolfers (2006) membahas kinerja pasar saham dari perusahaan di Amerika yang dipimpin oleh wanita. Menggunakan data dari S\&P 1500 perusahaan. Dia menemukan tidak ada perbedaan yang sistematis dalam return saham ketika perusahaan beroperasi pada lingkungan yang kompleks. Sassalos (2000) menganggap keberagaman pada jajaran direksi lebih efektif jika dibandingnkan dengan jajaran direksi yang homogen. Mereka berpendapat bahwa wanita akan meningkatkan pengambilan keputusan dengan membawa sudut pandang, dan pendapat yang berbeda kedalam diskusi. Eagly dan Carli (2003) menunjukkan bahwa gaya kepemimpinan wanita lebih efektif dalam lingkungan bisnis kontemporer. Mereka juga mencatat bahwa karena adanya suatu fenomena yang menghalangi perempuan untuk mendapatkan posisi yang tinggi dalam perusahaan, yang biasa dikenal glass ceiling phenomenon perempuan harus menunjukkan kompetensi tambahan untuk mencapai posisi manajerial dan dewan perusahaan.

H1 : Female executives sebagai direktur utama dan/ atau direktur keuangan badan usaha memiliki sifat konservatisme yang lebih tinggi terkait dengan kualitas laporan keuangan. 


\section{METODE}

Dalam penelitian ini yang menjadi variabel dependen adalah earnings management badan usaha yang dikaitkan dengan proksi discretionary accrual. Berikut ini adalah cara perhitungan discretionary accruals dengan menggunakan Modified Jones Dechow (1994):

$$
N D A C C=\frac{1}{T A_{t-1}}+\alpha_{1}\left(\frac{\Delta R E V-\triangle R E C}{T A_{t-1}}\right)+\alpha_{2} \frac{P P E}{T A_{t-1}}+\varepsilon
$$

Dimana :

$\mathrm{DA}=\frac{A C C-N D A C}{T A_{t-1}}$

ACC adalah total accrual (Net Income - Operating Cash Flow)

TA adalah total aset badan usaha pada tahun $\mathrm{t}-1 \mathrm{ke} \mathrm{t}$

$\triangle \mathrm{REV}$ adalah perubahan pendapatan badan usaha pada tahun $\mathrm{t}-1 \mathrm{ke} \mathrm{t}$

$\triangle \mathrm{REC}$ adalah perubahan pada piutang badan usaha pada tahun $\mathrm{t}-1 \mathrm{ke} \mathrm{t}$

PPEadalah nilai kotor dari property, plant, and equipment pada akhir tahun $t$

Eadalah unstandardized error

Setelah mengestimasikan dicretionary accruals, peneliti ingin mengetahui hubungan antara manajemen laba dan gender dari eksekutif perusahaan dengan rumus regresi berikut :

$$
\begin{aligned}
& \text { DAj, } t=\alpha_{0}+\beta_{1} \text { FEMALEj }, t+\beta_{2} \text { LEVj, } t+\beta_{3} \text { LOSSj, } t+\beta_{4} \mathrm{MBj}, t+ \\
& \quad \beta_{5} \text { REVGROWTHj, } t+\beta_{6} \text { SIZEj, } t+\sum_{k-1}^{n-1} \propto_{k} S_{I} C_{j}^{k}+\sum_{2012}^{2014} \omega_{y} Y E A R_{j}^{y}+\varepsilon_{j, t} \\
& \mathrm{H} 1: B 1 \neq 0
\end{aligned}
$$

Keterangan :

a. DA = Discretionary Accruals

b. FEMALE = Female Executives, 1 apabila CEO dan/ atau CFO badan usaha adalah perempuan dan jika tidak maka FEMALE $=0$

c. $\mathrm{LEV}=$ Leverage Ratio

d. LOSS = Negative Net Income, 1 apabila laba bersih periode berjalan adalah negatif dan jika laba bersih periode berjalan adalah positif maka LOSS $=0$

e. $\mathrm{MB}=$ Market to Book Ratio

f. REVGROWTH = Revenue Growth 
g. $\mathrm{SIZE}=$ Ukuran perusahaan

h. $\alpha=$ konstanta

i. $\beta=$ koefisien regresi untuk pengujian hipotesis

j. $\mathrm{SIC}=$ dummy variable berdasarkan kode klasifikasi standart industri.

$\mathrm{k} . \mathrm{YEAR}=$ dummy variable yang mengindikasikan tahun fiskal perusahaan.

1. $\varepsilon=$ error

\section{DATA}

Penelitian ini menggunakan data historis perusahaan berupa laporan keuangan yag telah diaudit dan laporan tahunan (annual report). Selain itu salah datu data diperoleh dari fact book yang diunduh dari situs resmi BEI. Data-data yang diperoleh dari laporan keuangan, annual report, dan fact book kemudian diolah menggunakan Microsoft Excel 2007 dan dilanjutkan dengan program SPSS 18.0 for windows.

Obyek dalam penelitian ini adalah perusahaan yang bergerak di sektor basic industry and chemichal, miscellaneous industry dan consumer goods industry serta terdaftar di Bursa Efek Indonesia (BEI) dan telah mengungkapkan jajaran direksi perusahan selama 3 tahun berturut-turut, yaitu 2012, 2013, dan 2014. Jumlah perusahaan dari tiga sektor tersebut pada tahun 2012 sebanyak 137 perusahaan, tahun 2013 sebanyak 142 perusahaan, dan tahun 2014 sebanyak 144 perusahaan. Total perusahaan dari ketiga sektor tersebut selama tahun 2012-2014 yaitu 423 sebanyak perusahaan. Dari sampel tersebut dilakukan criteria pemilihan sampel yang ditunjukkan oleh tabel 1

Dari tabel 1 dapat diketahui bahwa populasi awal dari penelitian berjumlah 423 perusahaan. Dari tabel diatas juga menunjukan proses pemilihan sampel untuk pengujian sehingga dari total populasi tersebut, hanya 342 perusahaan yang terpilih sebagai obyek dalam penelitian. 
Tabel 1. Kriteria Pengambilan Sampel Untuk Obyek Penelitian Keterangan $\begin{array}{llll}2012 & 2013 & 2014 & \text { Total }\end{array}$

Perusahaan yang bergerak di sektor sekunder yang terdaftar di BEI

Badan usaha yang menggunakan mata uang pelaporan selain Rupiah

$23 \quad 28 \quad 30 \quad 81$

Statistik deskriptif digunakan untuk mengetahui gambaran sampel yang digunakan dalam penelitian sehingga dapat menggambarkan populasinya. Statistik deskripif terdiri dari jumlah data, nilai minimum, nilai maksimum, rata-rata (mean) dan standar deviasi.

Tabel 2. Descriptive Statistics

\begin{tabular}{lccccc}
\hline & $\mathrm{N}$ & Minimum & Maximum & Mean & Std. Deviation \\
\hline size & 341 & 2.3978953 & 12.3717100 & 7.194155092 & 1.5558025624 \\
leverage & 341 & .0138480 & 2.8800000 & .507196708 & .3731306154 \\
mbratio & 330 & -8.9285714 & 53.5655058 & 2.989967439 & 6.5218008924 \\
revenuegrowth & 337 & -.7800264 & 7.0000000 & .175147262 & .5294920035 \\
dacc & 338 & -7.6418919 & 3.1409091 & -.563822285 & .9406782131 \\
Valid N (listwise) & 327 & & & & \\
\hline
\end{tabular}

Dari tabel 2, dapat dilihat bahwa jumlah observasi yang digunakan dalam penelitian ini adalah 343, namun data yang valid hanya 327, hal ini dikarenakan ada data perusahaan yang tidak lengkap. Nilai minimun dan nilai maksimum dari setiap variabe menunjukkan bahwa data yang digunakan untuk penelitian memiliki nilai dengan rentang (range) yang cukup besar. Nilai deviasi standar dari setiap variabel juga jauh berbeda dibandingkan dengan nilai mean-nya. Hal ini menunjukan bahwa nilai dari variabel-variabel tersebut sangat tersebar. 
Tabel 3. Statistik Deskriptif

\begin{tabular}{|c|c|c|c|c|c|}
\hline \multirow[t]{2}{*}{ Variabel } & \multicolumn{2}{|c|}{0} & \multicolumn{2}{|c|}{1} & \multirow[t]{2}{*}{ Total } \\
\hline & $(\mathrm{Nol}$ & emale) & & ale) & \\
\hline FEMALE & 268 & $78,36 \%$ & 74 & $21,64 \%$ & 342 \\
\hline
\end{tabular}

Setelah melihat tabel 3, diketahui bahwa dari variabel FEMALE terdapat 74 sampel atau 21,64\% dari total sampel yang memiliki eksekutif badan usaha dengan gender perempuan. Eksekutif badan usaha sebagaimana dimaksud adalah Chief Executive Officer (CEO) atau Chief Financial Officer (CFO). Sedangkan, sebanyak 268 sampel atau 78,36\% dari total sampel ternyata tidak memiliki eksekutif badan usaha dengan gender perempuan. Sehingga dapat disimpulkan bahwa sebagian besar badan usaha yang bergerak di sektor basic industry, miscellaneous, consumer goods sebagian besar tidak memiliki Chief Executive Officer (CEO) atau Chief Financial Officer (CFO) perempuan.

Tabel 4. Statistik Deskriptif

\begin{tabular}{|c|c|c|c|c|c|}
\hline \multirow[t]{2}{*}{ Variabel } & \multicolumn{2}{|c|}{0} & \multicolumn{2}{|c|}{1} & \multirow[t]{2}{*}{ Total } \\
\hline & & fit) & & Ss) & \\
\hline LOSS & 287 & $83,92 \%$ & 55 & $16,08 \%$ & 342 \\
\hline
\end{tabular}

Setelah melihat tabel 4, diketahui bahwa dari variabel LOSS terdapat 55 sampel atau $16,08 \%$ dari total sampel yang menghasilkan net loss pada tahun berjalan. Apabila pada tahun berjalan, badan usaha menghasilkan laba maka nilai variabel ini adalah 0 dan begitu sebaliknya. Sebanyak 287 sampel atau 83,92\% dari total sampel ternyata menghasilkan profit pada tahun berjalan. Sehingga dapat disimpulkan bahwa sebagian besar badan usaha yang bergerak di sektor basic industry, miscellaneous, consumer goods menghasilkan profit atas aktivitas bisnisnya selama satu periode. 
Setelah melihat tabel 5, diketahui bahwa dari variabel basic industry terdapat 159 sampel atau 46,49\% dari total sampel pada tahun berjalan. Variabel miscellaneous terdapat 72 sampel atau $21,05 \%$ dari total sampel pada tahun berjalan. Sedangkan variabel consumer goods terdapat 111 sampel atau 32,46 dari total sampel pada tahun berjalan. Sehingga dapat disimpulkan bahwa dirangking proporsi sampel yang digunakan pada penelitian ini hampir setengah dari sampel merupakan perusahaan yang bergerak pada sektor basic industry.

Tabel 5. Statistik Deskriptif

Basic Industry Miscellaneous Consumer Goods Total


Tabel 6. Korelasi

\begin{tabular}{|c|c|c|c|c|c|c|c|c|c|c|c|c|}
\hline & fexec & basicindustry & miscellaneous & consumergoods & dummy2012 & dummy 2013 & dummy2014 & size & leverage & loss & mbratio & revenuegrowth \\
\hline dacc & -0.64 & 0.078 & 0.052 & $-0.128 *$ & $0.394^{* *}$ & $-0.227^{* *}$ & $-0.165 * *$ & 0.024 & -0.084 & 0.047 & -0.062 & 0.008 \\
\hline female & & $-0.146^{* *}$ & -0.017 & $0.170^{* *}$ & -0.005 & -0.005 & 0.010 & -0.072 & $-0.134^{*}$ & -0.079 & -0.039 & -0.047 \\
\hline basicindustry & & & $-0.481 * *$ & $-0.646 * *$ & 0 & 0 & 0 & $0.128^{*}$ & 0.014 & 0.104 & $\begin{array}{l}-0.141^{*} \\
-\end{array}$ & 0.003 \\
\hline miscellaneous & & & & $-0.358^{* *}$ & 0 & 0 & 0 & 0.032 & $0.17^{* *}$ & 0.008 & $0.153^{* *}$ & -0.033 \\
\hline consumergoods & & & & & 0 & 0 & 0 & $0.108^{*}$ & $0.164^{* *}$ & $-0.117 *$ & $0.284^{* *}$ & 0.026 \\
\hline dummy 2012 & & & & & & $-0.5^{* *}$ & $-0.5^{* *}$ & -0.084 & -0.013 & $-0.122^{*}$ & -0.006 & -0.05 \\
\hline dummy 2013 & & & & & & & $-0.5^{* *}$ & 0.013 & 0.009 & 0.095 & 0.008 & -0.019 \\
\hline dummy2014 & & & & & & & & 0.07 & 0.004 & 0.027 & -0.001 & 0.068 \\
\hline size & & & & & & & & & -0.085 & $-0.152 * *$ & $0.182^{* *}$ & -0.068 \\
\hline leverage & & & & & & & & & & $0.378^{* *}$ & 0 & 0.011 \\
\hline loss & & & & & & & & & & & -0.065 & -0.048 \\
\hline mbratio & & & & & & & & & & & & 0.41 \\
\hline
\end{tabular}

Keterangan: Tabel ini menggambarkan korelasi antara variabel yang digunakan dalam regresi.

Korelasi menggunakan pearson correlation.

* = Tingkat korelasi 0.05

$* *=$ Tingkat korelasi 0.01 


\section{HASIL DAN PEMBAHASAN}

\subsection{Hasil Regresi}

Tabel 7. Hasil Regresi

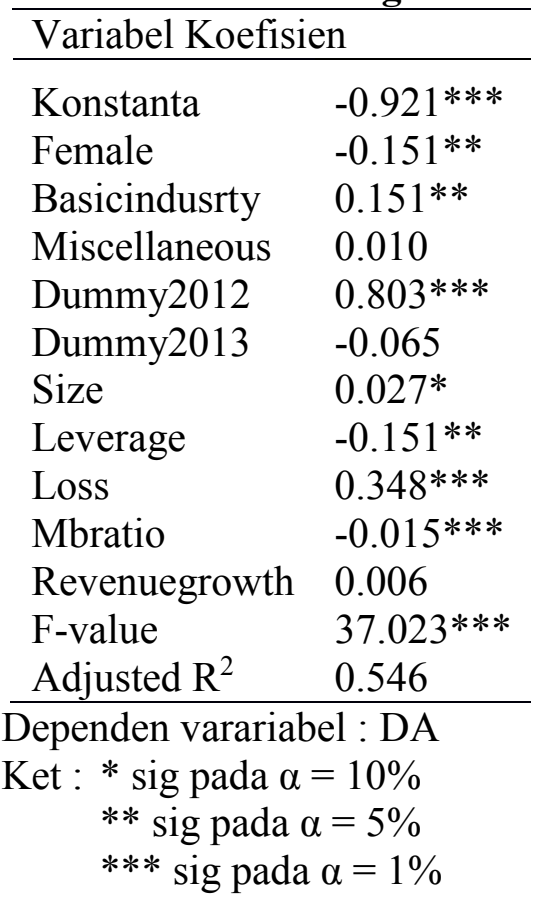

Dari pengujian yang dilakukan terhadap variabel FEMALE, ditemukan bahwa variabel Female berpengaruh negatif signifikan. Hasil ini sesuai dengan penelitian Peni dan Vahamaa (2010) bahwa perusahaan dengan Chief Executive Officer (CEO) atau Chief Financial Officer (CFO) perempuan lebih memakai strategi pelaporan yang konservatif. Hal ini juga dikarenakan bahwa perempuan memliki sifat konservatif yang lebih tinggi dibandingkan dengan laki-laki. Khan dan Vieito (2013) yang menyatakan bahwa badan usaha yang memiliki Chief Executive Officer (CEO) perempuan berhubungan dengan peningkatan kinerja perusahaan dibandingkan dengan badan usaha yang dikelola oleh CEO laki-laki. Kelebihan sifat dan sikap yang dimiliki perempuan memberi bukti bahwa untuk mempertahankan posisi mereka sebagai eksekutif maka ia akan cenderung tidak bersikap konservatif. Penelitian Gulzar dan Wuhan (2011) yang menyatakan bahwa kehadiran perempuan di posisi eksekutif badan usaha akan membantu untuk mengurangi earningsmanagement yang terjadi. Oleh karena itu dapat disimpulkan bahwa terlepas dari motivasi dan pola manajemen laba, eksekutif 
perempuan sebagai pimpinan badan usaha mempunyai kecenderungan lebih konservatif dalam melaporkan laba dibanding eksekutif laki-laki.

Basic industryberpengaruh positif signifikan terhadap DA. Hal ini dikarenakan sampel perusahaan pada penelitian ini sebanyak 46,49\% terdiri dari sektor basic industry, atau data yang digunakan banyak terdapat pada sektor basic industry daripada di dua sektor lainnya.

Dalam penelitian ini variabel Size tidak memiliki pengaruh yang sinifikan terhadap DA. Hasil ini sesuai dengan penelitian Chen et al. (2005) dan Rusmin (2010) bahwa tidak adanya pengaruh yang signifikan antara SIZE dan DA sehingga tidak dapat dikatakan bahwa skala bisnis suatu badan usaha akan menjadi motivasi dari manajemen untuk melakukan praktik manajemen laba, hal ini dikarenakan semakin besar perusahaan mungkin memiliki struktur yang kuat, menurunkan ketidakseimbangan informasi yang diterima, dan pada umumnya dilakukan pengawasan yang lebih ketat oleh auditor dan analis keuangan (Meek et al., 2007). Sebaliknya, hasil ini justru tidak sesuai dengan penelitian Peni dan Vahamaa (2010) bahwa SIZE akan berpengaruh signifikan terhadap DA dan dapat dijadikan indikasi adanya praktik manajemen laba (earningsmanagement). Perbedaan hasil ini bisa dikarenakan perbedaan sampel yang diambil.

Dari pengujian yang dilakukan terhadap variabel LEV berpengaruh negatif signifikan. Hasil ini sesuai dengan penelitian Peni dan Vahamaa (2010) bahwa variabel LEV berpengaruh negatif signifikan terhadap DA. Konsep dasar agency theory dalam hasil penelitian mendukung nilai koefisien (beta) yang menjelaskan bahwa semakin tinggi tingkat LEV maka akan semakin besar kontrol pihak eksternal (bondholders) terhadap perusahaan (agent) sehingga kemungkinan melakukan manipulasi semakin kecil. Hal ini sesuai dengan pernyataan Berger dan Patti (2006) dimana menurut agency cost hypothesis, maka leverage yang tinggi atau rasio ekuitas dibanding aset yang rendah akan mengurangi agency cost. Oleh karena itu, LEV berpengaruh negatif signifikan terhadap praktik manajemen laba.

Namun, hasil penelitian ini ternyata berbeda dengan penelitian DeAngelo etal. (1994) dalam Peni dan Vahamaa (2010), Healy dan Palepu (1990), Pressdan 
Weintrop (1990) dalam Rusmin (2010), serta penelitian DeFond danJiambalvo (1994), Sweeney (1994) dalam Chen et al. (2005) bahwaleverage memilikipengaruh positif signifikan terhadap earnings management.Diketahui bahwa variabel LEV menunjukkan proporsi sumberdana eksternal badan usaha terhadap seluruh sumber daya yang dimilikibadan usaha. Berbeda dengan konsep dasar agency theory, positiveaccounting theory (Watts dan Zimmerman, 1990) dalam Scott (2009: 287)menyatakan bahwa menurut hipotesis debt covenant, risiko keuangan yangdihadapi badan usaha akan meningkat saat nilai leverage semakin besar.

Variabel Loss berpengaruh positif signifikan terhadap DA, tingkat signifikansi sebesar 0,000. Hal ini sesuai dengan apa yang diungkapkan oleh Peni dan Vahamaa (2010), loss merupakan sala satu proksi yang dapat menggambarkan kondisi keuangan badan usaha. Oleh karena itu, Loss secara potensial akan berpengaruh terhadap kecenderungan praktik manajemen laba. Hasil ini sesuai dengan penelitian Burgstahler dan Dichev (1997) bahwa ketika badan usaha sedang mengalami kerugian, maka badan usaha tersebut akan cenderung melakukan manajemen laba. Hasil penelitian ini justru tidak sesuai dengan penelitian Chen et al. (2005) bahwa Loss tidak dapat dijadikan indikasi adanya earnings management. Hal ini dapat terjadi karena loss bukan merupakan satu-satunya pemicu yang signifikan terhadap terjadinya praktik manajemen laba.

M/B Ratio berpengaruh negatif signifikan terhadap DA, nilai signifikansi sebesar 0,000. Menurut Gitman (2006) badan usaha yang memiliki $M / B$ ratio tinggi diharapkan dapat melakukan hal yang lebih baik daripada badan usaha dengan nilai $M / B$ ratio yang rendah. Hal ini dikarenakan, menurut Meek et al., (2007) semakin besar perusahaan mungkin memiliki struktur yang kuat, menurunkan ketidakseimbangan informasi yang diterima, dan pada umumnya dilakukan pengawasan yang lebih ketat oleh auditor dan analis keuangan. Oleh karena itu M/B ratio semakin besar semakin kecil kecenderungan manajemen untuk melakukan earnings management.

Variabel REVGROWTH tidak berpengaruh signifikan terhadap DA. Hasil ini tidak sesuai dengan yang diungkapkan oleh Peni dan Vahamaa (2010) 
dalam penelitian nya, dimana REVGROWTH memiliki pengaruh yang signifikan terhadap DA. Hasil dari penelitian ini menunjukkan bahwa REVGROWTH tidak memiliki pengaruh secara signifikan terhadap DA sehingga dapat disimpulkan bahwa growth opportunities dari badan usaha tidak menentukan besarnya praktik manajemen laba.Ketidaksesuaian hasil dengan penelitian Peni dan Vahamaa (2010) dapat terjadi karena adanya perbedaan sampel penelitian.

\section{KESIMPULAN}

Dari hasil analisis dan pengolahan data, maka didapatkan hasil sebagai berikut :

Hasil uji pada variabel independen FEMALE berpengaruh negatif signifikan terhadap variabel dependen DA. Oleh karena itu, ketika investor ingin melihat praktik manajemen laba (earning management) pada perusahaan, maka investor dapat mempertimbangkan faktor gender kepemimpinan yaitu FEMALE. Hal ini disebabkan karena faktor tersebut memiliki pengaruh negatif signifikan terhadap nilai discretionary accrual. Hal ini mengindikasikan bahwa CEO (Chief Executive Officer) dan CFO (Chief financial Officer) wanita cenderung lebih menghindari melakukan earnings management.

Hasil uji pada variabel kontrol, yaitu leverage, menunjukkan pengaruh negatif yang signifikan terhadap discretionary accrual sebagai proksi dari earnings management artinya semakin kecil nilai dari variabel ini maka akan semakinmeningkatkan kemungkinan earnings management, temuan ini sesuai dengankonsep agency theory.

Hasil uji pada variabel kontrol loss menunjukkan pengaruh yang signifikan terhadap discretionary accrual sebagai proksi dari earnings management artinya semkain besar nilai loss semakin besar kemungkinan terjadi earnings management. Selain itu uji pada variabel kontrol M/B ratio berpengaruh negatif signifikan terhadap discretionary accrual sebagai proksi dari earnings management artinya semakin kecil nilai $\mathrm{M} / \mathrm{B}$ ratio semakin meningkat kemungkinan untuk terjadinya praktik earnings management. 
Sebaliknya, hasil uji pada model regresi untuk variabel independen sekaligus variabel kontrol revenue growth; dan size menunjukkanbahwa seluruh variabel tersebut tidak berpengaruh signifikanterhadap discretionary accrual yang merupakan proksi dari earnings management. Oleh karena itu, ketika investor ingin melihat praktikmanajemen laba (earnings management) pada badan usaha melaluinilai discretionary accrual yang dihasilkan, maka investor dapatmengabaikan faktor-faktor seperti revenue growth dan size. Hal ini disebabkan karena faktor-faktortersebut diketahui tidak memiliki pengaruh signifikan terhadap nilai discretionary accrual.

\subsection{Keterbatasan penelitian}

Sampel yang digunakan pada penelitian ini diambil dari perusahaan industri manufaktur yang bergerak di sektor sekunder. Hal ini berakibat rendahnya kekuatan statistik dari hasil pengujian.

Biasnya makna gender dalam penelitian. Gender pada dasarnyamemiliki makna yang lebih luas jika dibandingkan dengan maknadari jenis kelamin. Pada dasarnya, gender mencakup gayakepemimpinan, kemampuan komunikasi, tingkat risiko danpengambilan keputusan seseorang (Peni dan Vahamaa, 2010). Tidakmenutup kemungkinan bahwa seorang laki-laki dapat memiliki gayakepemimpinan feminist dan seorang perempuan dapat memiliki gayakepemimpinan masculine. Oleh karena itu, biasnya makna gender menjadi salah satu kekhawatiran bahwa data tidak mencerminkankondisi yang sebenarnya terjadi.

Penelitian ini hanya terbatas pada jenis kelamin direktur utama dan/atau direktur keuangan badan usaha yang menjadi sampel penelitian,dimana tidak mempertimbangkan karakteristik kepemimpinanseseorang yaitu usia, status (kawin/ belum kawin), lamanya menjabat dan karakteristik lainnya.

Periode penelitian yang digunakan hanya terdiri dari tiga periodeyaitu 2012-2014 serta penelitian yang dilakukan hanya berfokuspada sektor sekunder badan usaha yangterdaftar di Bursa Efek Indonesia (BEI). Hal ini menyebabkan hasilpengujian atas model regresi kurang komprehensif dalam jangkapanjang, 
yaitu tidak mampu memperlihatkan pengaruh female executives terhadap earnings management pada siklus bisnis yangberbeda.

\section{DAFTAR PUSTAKA}

Adams, R. and Ferreira, D. (2009), "Women in the boardroom and their impact on governance and performance”, Journal of Financial Economics, Vol. 94, pp. 291309.

Altintaş, F. C., Altintaş, M. H. (2008). The relationship between feminist/womanist identity and leadership styles of women managers in Turkey. Gender in Management: An International Journal, 23(3), 175-193.

Beneish, M.D. (2001). Earnings Management: A Perspective. Managerial Finance 27 (12) : 3-17.

Burgstahler dan I. Dichev. (1997). Earnings, Adaptation, and Equity Value. The Accounting Review

Campbell, K. and Minguez-Vera, A. (2008), "Gender diversity in the boardroom and firm financial performance", Journal of Business Ethics, Vol. 83, pp. 435-51.

Carter, D., Simkins, B. and Simpson, W. (2003), "Corporate governance, board diversity, and firm value”, The Financial Review, Vol. 38, pp. 33-53.

Chen, et al. 2005. Detecting Earnings Management. Journal of Intellectual Capital, Vol 6 , Issue 2.

Darmadi, Salim. 2013. Do Women in Top Management affect firm Performance? Evidence from indonesia. Corporate Governance. Vol. 13 No. 3, pp288-304.

Dechow, et al. 1995. Detecting Eanings Management. The Accounting Review. Vol. 70 No. 2, pp193-225

Eagly, A. and Carli, L. (2003), "The female leadership advantage: an evaluation of the evidence”, The Leadership Quarterly, Vol. 14, pp. 807-34.

Efferin, S., Darmadji, S.H., dan Tan, Y. (2008). Metode Penelitian Akuntansi: Mengungkap Fenomena dengan Pendekatan Kuantitatif dan Kualitatif, cetakan pertama. Graha Ilmu: Yogyakarta.

Erhardt, N., Werbel, J. and Shrader, C. (2003), "Board of director diversity and firm financial performance", Corporate Governance: An International Review, Vol. 11, pp. 102-10.

Farrell, K. and Hersch, P. (2005), “Additions to corporate boards: the effect of gender', Journal of Corporate Finance, Vol. 11, pp. 85-106.

Fondas, N. and Sassalos, S. (2000), "A different voice in the boardroom: how the presence of women directors affects board influence over management", Global Focus,Vol.12, pp. 13-22. 
Gitman, Lawrence J, 2006, Principles of Managerial Finance (11th ed.), Boston: Addison Wesley

Kieso, D. E., Weygandt, J. J., Warfield, T. D. 2011. Intermediate Accounting IFRS Edition. Volume Pertama. United States of America: John Wiley \& Sons Inc.

Lako, Andreas. 2007, Laporan Keuangan dan Konflik Kepentingan, cetakan pertama. Amara Books: Yogyakarta.

Maxmonroe. 2015. 3 Pengusaha Wanita Indonesia Dengan Pengaruh Besar di Asia.https://www.maxmanroe.com/3-pengusaha-wanita-indonesia-denganpengaruh-besar-di-asia.html (diakses tanggal 20 maret 2016)

Meek, G., Rao, R. and Skousen, C. (2007), "Evidence on factors affecting the relationship between CEO stock option compensation and earnings management", Review of Accounting and Finance, Vol. 6, pp. 304-23.

Mosse, J.C., 1996, Gender dan Pembangunan, Pustaka Pelajar, Yogyakarta.

Nugraha Rizki. 2015. Daftar tangkapan terbesar KPK. http://www.dw.com/id/daftartangkapan-terbesar-kpk/a-18214980 (diakses tanggal 15 juli 2016)

Nugroho, Hastanti.W. (2004). Diskriminasi Gender (Potret Perempuan Dalam Hegemoni Laki-laki) Suatu Tinjauan Filsafat Moral. Cetakan Pertama. Hanggar Kreator : Bantul Jogjakarta.

Peni, Emilia dan Sami Vahamaa. 2010. "Female Executive and Earnings Management". Managerial Finance Journal, Vol.36, No.7, hal. 629-645.

Rose, C. (2007), “Does female board representation influence firm performance? The Danish evidence", Corporate Governance: An International Review, Vol. 15 No. 2, pp. 404-13.

Rusmin. 2010. "Auditor Quality and Earnings Management: Singaporean Evidence". Managerial Auditing Journal, Vol. 25, No. 7, pp. 618-638.

Santoso Singgih. 2015, Menguasai Statistik Parametrik, cetakan pertama. Elex Media Komputindo: Jakarta.

Satwika, Anisa dan Theresia Woro Damayanti. 2005. "Deteksi Manajemen LabaMelalui Beban Pajak Tangguhan.” Jurnal Ekonomi dan Bisnis Indonesia,Vol. XI, No. 1, hal $119-134$.

Scott, William R, 2009. Financial Accounting Theory. Fifth Edition. Canada Prentice Hall.

Sri Sulistyanto, 2008. Manajemen Laba teori dan model empiris, Jakarta : Grasindo.

Yukl, Gary, 2010, Kepemimpinan dalam Organisasi, Edisi Kelima. Jakarta: PT. Indeks.

Watson, J. (2002), "Comparing the performance of male- and female-controlled businesses: relating outputs to inputs", Entrepreneurship Theory and Practice, Vol. 26 No. 3, pp. 91-100. 
Arief Kusumo Atmojo Sugiharto, PengaruhFemale Executive Terhadap Kualitas Laporan Keuangan Pada Sektor ManufakturYang Terdaftar Di BEI Periode 2012-2014

Wolfers, J. (2006), "Diagnosing discrimination: stock returns and CEO gender", Journal of the European Economic Association, Vol. 4 Nos 2/3, pp. 531-41. 